\title{
Medicolegal
}

\section{Impaired driving: responsibility from a distance}

\author{
BY OUR LEGAL CORRESPONDENT
}

The approach of the season of good cheer and overflowing cupsand casualty wards-should focus attention on the legal responsibility of the generous host, the lacer of drinks, and others who contribute at a distance to injuries caused by impaired driving.

Driving a vehicle with more than the permitted amount of alcohol in the bloodstream is an absolute offence, so it is no defence that someone may have laced the driver's drink without his knowledge, causing him to go unintentionally over the limit. But this line of argument is often advanced by the defence in such cases because it may provide a "special reason" for not imposing the otherwise mandatory disqualification from driving.

The very frequency of this line of defence has led the police to prosecute individuals alleged to have laced the drink. At first some courts thought that the person who put additional spirits in someone's drink could not be guilty of an offence, but in 1975 the Court of Appeal held that such a person may be guilty of that variant of aiding and abetting known as "procuring," and it is a statutory offence to "aid, abet, counsel, or procure" the commission of an offence. ${ }^{2}$

When a man surreptitiously laced his companion's drink and as a result caused him to commit the offence of driving with excess alcohol, which the companion would not have done otherwise, then the lacer is guilty of procuring that offence. The court expressly declined to consider what would be the position if the lacing was known to the driver. To prove guilt of procuring the offence it would be necessary to prove that the accused knew that his companion was going to drive and knew that the natural result of adding the alcohol would be to bring him over the legal limit.

The position of the generous host was also considered in the same case, though not decided. The court did, however, favour the view that in normal circumstances where a guest knows perfectly well how much he has had to drink it is usually proper (so far as the criminal law is concerned) to leave him to make his own decision whether to have another drink. Different considerations might apply in very exceptional circumstances-for example, if the guest had never drunk alcohol before or if the guest were young and inexperienced by comparison with the host.

What is the position of the publican or wine and spirits merchant who sells alcohol to a motorist who later drives a vehicle under the influence of alcohol? Only in very rare cases could a publican or trader be charged with aiding and abetting or procuring. The position is governed by the same rules as would apply to the sale of any article (for example, an axe) for the purpose of committing a criminal offence. ${ }^{3}$ To secure a conviction of the seller the prosecution would have to prove that the seller knew that the buyer intended to use the article for the purpose of the sort of crime that the buyer in fact later committed. Mere suspicion that a crime was intended would not be enough. Such knowledge could rarely be proved on a sale of alcohol. Even if a publican saw a customer drive up to his public house and then served him with more drinks than a driver could legally have the prosecution would find it difficult to prove that the publican knew that the customer intended to drive away rather than call a taxi or get a lift from a friend. But in some cases such knowledge might be proved either from past conduct or from what was said before the drinks were served.

\section{Liability for damages}

Quite apart from liability in criminal law there may be civil liability for damages. The common law imposes a duty towards "persons who are so closely and directly affected by my act that I ought reasonably to have them in contemplation when I am directing my mind to the acts or omissions which are called in question." In general, one is not liable for injury done by third parties (apart from one's servants or agents), but liability may arise in special circumstances.

As early as 1905 the Court of Appeal of Ireland held that a railway company may be liable for injury to a passenger caused by another passenger. ${ }^{5} \mathrm{~A}$ drunk cattledealer allowed on to the platform at Omagh station smashed a carriage window, injuring a passenger's eye. The Court of Appeal held that if the ticket collector allowed on to the platform a man who was "obviously drunk" it became the duty of the company to take due and reasonable care to prevent any injury to other passengers arising from his condition.

More recently the Supreme Court of Canada upheld a judgment in favour of a customer of a hotel who complained that he was injured by a passing car when walking home after being ejected drunk from a hotel. ${ }^{6}$ But the court made it plain that if the hotel's only action had been the supplying of beer to the customer its management would not have been liable for injuries suffered by the customer after leaving. Liability arose from the facts that the customer was accepted into the hotel's drinking parlour by staff who knew that he acted recklessly when drunk, that he was drunk when ejected, and that he would have to go home, probably on foot, along the main highway. The staff should either have arranged for the customer to be taken home by the police, or by taxi, or by someone willing to give him a lift; failing that, he should have been lodged for the night in one of the hotel's bedrooms. Undoubtedly if the same man had injured someone else, either by causing a passing car to swerve or by getting into a car and driving it dangerously, the hotel management would have been held equally liable. Equally, there is little doubt that the reasoning of this case would be applied in England and Wales, hedged about with similar limitations.

Two recent decisions in the United States have gone even further. The Supreme Court of New Jersey held that a generous host might be liable to pay damages. ${ }^{7}$ The victim of a car accident alleged that the accident had been caused by a driver who had been drinking whisky at the home of the defendant hosts about an hour earlier. The court held that an action for common law negligence may be brought where a social host directly serves alcohol to an adult social guest and continues to do so even after the guest is visibly intoxicated, provided the host knows that the guest will soon be driving home. In principle there is no reason why the law of England and Wales should not in the future be stated in similar terms. But how often does a host know that his guest will drive himself home rather than be driven by a spouse, friend, or taxi driver?

In Wisconsin the Supreme Court held that a retailer could be made liable to victims of an accident occurring after sale of alcohol to a minor in breach of the criminal law. ${ }^{8}$ Overruling previous 
decisions the court held that a vendor who negligently supplied a minor with alcohol, which causes intoxication or impairment of the minor's driving ability, is liable to third persons in the proportion that the negligence in selling the alcohol was a substantial factor in causing the injuries. In England and Wales such liability could exist only either at common law or framed as a breach of statutory duty if the retailer knew or ought to have known that the purchaser was intending to or was likely to drive a motor vehicle and that he was intending to or was likely to drink before (rather than after) driving sufficient alcohol to impair his driving substantially. The fact that the purchaser was under age for the purchase of alcohol would be a factor for consideration but would not of itself give rise to liability.

It may well be that actions along these lines will be taken in the future. In Britain there is not such a great incentive to search for additional defendants having regard to the more comprehensive insurance cover required of motorists here and having regard to the back stop cover provided by the Motor Insurer's Bureau in the case of uninsured motorists. But as the costs of motor insurance increase the insurers themselves may seek contributions from people other than motorists directly concerned. In the long run this may tend only to spread the load on to other insurance risks, such as the third party risk cover usually included in a householder's policy. Eventually, teetotallers may get special rates on their householder's policies, just as smokers ought to already. On the other hand, and more desirably, a change in social customs might be achieved.

\section{References}

I Attorney General's Reference No 1 of 1975 [1975] QB773.

Accessories and Abettors Act, 1861, section 8 .

3 R $v$ Bainbridge [1960] l QB 129.

Donoghue $v$ Stevenson [1932] AC 567,579 per Lord Atkin

Adderley $v$ Great Northern Railway Company [1905] 2 1. R. 378

Jordan House $v$ Menow and Housberger (1973)38DLR 3d 105

Kelly $v$ Gwinnell, June $27,1984,476$ A.2d 1219

\title{
Around Europe
}

\section{Two cases of falciparum malaria acquired in Britain}

\author{
DONALD WHITFIELD, C F CURTIS, G B WHITE, G A T TARGETT, D C WARHURST, \\ D J BRADLEY
}

\begin{abstract}
Two cases of severe falciparum malaria contracted in the United Kingdom occurred in residents of Sussex, living 10 and $15 \mathrm{~km}$ from Gatwick airport. One patient was the landlord of a public house much frequented by aircrew, and the other was the wife of a worker at the airport, who travelled close to the public house on the probable date she contracted her infection. Transmission was most probably due to the bite of an infected imported tropical anopheline mosquito transported in a vehicle from the aircraft to the site of transmission during the very hot and humid weather of July 1983.
\end{abstract}

Prevention of further cases depends on increased diligence in "blocks-away" destruction of insects in aircraft flying from endemic areas, but there is a need for more study of acceptable alternative ways of delivering the insecticide. This "airport

Crawley Hospital, Crawley, Sussex RH11 7DH

DONALD WHITFIELD, MA, FRCP, consultant physician

Division of Communicable and Tropical Diseases, London School of Hygiene and Tropical Medicine, London WC1E 7HT

C F CURTIS, BA, PHD, Medical Research Council external staff senior lecturer in entomology

G B WHITE, PHD, ARCs, senior lecturer in entomology

G A T TARGETT, PHD, DSC, professor of immunology of protozoal diseases

D C WARHURST, PHD, MRCPATH, senior lecturer in medical protozoology, and microbiologist, Public Health Laboratory Service Malaria Reference Laboratory

D J BRADLEY, DM, FRCPATH, professor of tropical hygiene, codirector of Public Health Laboratory Service Malaria Reference Laboratory

Correspondence to: Dr C F Curtis. malaria" is well recognised on the continent, and physicians should be aware of its existence in those who have not travelled abroad but live or work near international airports.

\section{Introduction}

Malaria infections are often contracted in the tropics, with the disease developing after the patient has come to a temperate country. Between one and two thousand such cases have been seen in Britain annually in recent years.' Transmission of malaria within England has occurred in the past, but the last reported case of indigenous malaria in Great Britain was in 1953. ${ }^{2}$

Nevertheless, two patients with proved falciparum malaria were admitted to Crawley Hospital, Sussex, in August 1983 having contracted the disease in Britain. This paper describes the clinical and epidemiological aspects of these two patients and discusses the entomological investigations made to determine the likely source of infection. A fuller account of the entomological basis is available elsewhere. ${ }^{3}$

\section{The patients}

CASE 1

On 2 August 1983 a 48 year old publican was admitted semicomatose and delirious to the isolation ward of Crawley Hospital. The history was obtained partly from his general practitioner's referral letter and partly from his wife. A fortnight previously he had felt nauseated, lost his appetite, and developed a severe headache. The next day he had felt worse, developed a fever associated with sweating and rigors, and also had bouts of vomiting and diarrhoea. Two days after the onset of his illness he called in his general 